\title{
Victims’ Rights in Criminal Trials: Prospects for Participation
}

\author{
Jonathan Doak*
}

Victims in common law jurisdictions have traditionally been unable to participate in criminal trials for a number of structural and normative reasons. They are widely perceived as 'private parties' whose role should be confined to that of witnesses; and participatory rights for such third parties are rejected as a threat to the objective and public nature of the criminal justice system. However, recent years have witnessed both a major shift in attitude in relation to the role of victims within the criminal justice system and a breakdown in the public / private divide in criminal justice discourse. This article considers the standing of the victim within the criminal trial against the backdrop of such changes, and examines the arguments for a more radical course of reform that would allow victims to actively participate in criminal hearings as they are able to do in many European jurisdictions.

\section{INTRODUCTION}

The plight of the victim within the criminal justice system has been widely documented since the 1970's, but during the past two decades the interests of victims have come to play a more prominent role in the formulation of policy in both domestic and international criminal justice systems. In the UK, successive governments have introduced a range of measures designed to bolster the so-called 'social' or 'service' rights of the victim, such as improved access to information, upgraded court facilities, and entitlements to compensation. A wide range of statutory measures is now available to assist vulnerable witnesses to give evidence at court, ${ }^{1}$

\footnotetext{
* Department of Law, University of Sheffield, Conduit Road, Sheffield, S10 1FL.

A previous version of this paper was presented at the SLSA Conference in April 2004 at the University of Glasgow. Thanks to John Jackson and Sean Doran, and to the anonymous reviewers.

${ }^{1}$ The Youth Justice and Criminal Evidence Act 1999 introduced a range of 'special measures' for vulnerable witnesses testifying in court. Witnesses eligible under the Act may be entitled to use a range of measures to maximise the quality of their evidence. The measures include the erection of physical screens; the use of live televised links; removal of the public from the courtroom in certain sexual offences cases; the removal of gowns and wigs; the admission of both pre-recorded examination-in-
} 
and the new Domestic Violence, Crime and Victims Act brings into effect a statutory code of practice for criminal justice agencies and creates a new 'Victims' Commissioner' to promote and protect the interests of victims and witnesses. ${ }^{2}$

On the whole, such reforms have been broadly welcomed and have proved relatively non-contentious. They can be said to emanate primarily from the victims' emerging status as consumers of the criminal justice services, ${ }^{3}$ and it is largely agreed that they threaten neither the public character of the criminal justice system nor the due process rights of the accused. Yet many proponents of victims' rights view such developments as long overdue, and argue that the idea of victims' rights should be developed one step further, entailing some form of procedural right of participation within criminal proceedings. The concept of 'participation' is something of an abstract term and lacks any concrete definition. Edwards has suggested that it may be perceived as stemming from the broader concept of citizenship, and may include 'being in control, having a say, being listened to, or being treated with dignity and respect'. ${ }^{4}$ Interpreted in this way, 'participation' in criminal justice may appear both feasible and desirable, but the debates around the extent of participation to which victims ought to be entitled touch upon the much deeper issue of how far the interests of a third party ought to be accommodated within the traditionally dichotomous nature of the criminal trial between the State and the accused. If, as most theorists state, the main function of the criminal justice system ought to be the punishment of the guilty and the acquittal of the innocent, ${ }^{5}$ questions need to be addressed concerning the proper place of the 'private' interests of a third party in a system where the State is charged with protecting the public interest and safeguarding core values such as certainty and objectivity.

In recent years, the 'public' nature of key decision-making processes has been increasingly influenced by private interests, with victims in some jurisdictions having acquired the right to participate in sentencing and diversion processes. Following the

chief and cross-examination as alternatives to live testimony; and the use of intermediaries or 'aids to communication'.

${ }^{2}$ See sections 33 and 48 the Act respectively.

${ }^{3}$ D. Faulkner, Crime, State and Citizen (2001), 232.

${ }^{4}$ I. Edwards, 'An Ambiguous Participant: The Crime Victim and Criminal Justice Decision-Making' (2004) 44(6) Br. J. Crim. 967, 973.

${ }^{5}$ A. Sanders and R. Young, Criminal Justice (2000), 9. 
establishment of several pilot schemes in England in the late 1990's, the Government introduced a nationwide Victim Personal Statement Scheme in October 2001, which allows victims to explain the impact of the crime upon them by way of a personal statement made to the police. ${ }^{6}$ The specific merits and potential pitfalls of the participation in sentencing are widely discussed elsewhere, ${ }^{7}$ but the notion of victim 'participation' implies much more than the giving of some form of victim impact statement. In the common law world, relatively little attention has been given to the concept of direct participation rights for victims within the criminal trials where the guilt of the accused remains an issue. In the pre-conviction phase of criminal proceedings, the aims and objectives of proceedings are different from the sentencing stage of proceedings where guilt is no longer an issue. The concept of victim involvement here is fraught with numerous difficulties on account of the myriad of competing aims of criminal justice, which include the objective adjudication of guilt, the desirability of truth-finding, the preservation of public interests, and the need to preserve fair trial rights for the accused. It is additionally complicated by the fact that his or her status as a 'victim' is somewhat uncertain prior to the determination of the accused's guilt. ${ }^{8}$

Recently, however, some adversarial systems have introduced mechanisms whereby the victim's legal representative may intervene in relation to specific issues arising in the trial. For example, the Republic of Ireland adopted legislation in 2001 to permit complainants to be represented by their own counsel in a voir dire where the defence had applied to introduce previous sexual history evidence. ${ }^{9}$ However, the provision is extremely narrow, in so far as it will only apply in cases of rape or sexual assault, and,

\footnotetext{
${ }^{6}$ The Statement is appended to the case papers, but does not have the same effect as those types of victim impact statements that are used as sentencing tools in parts of the USA and Canada. It was made clear in a Practice Direction from the Lord Chief Justice that the 'opinions of the victim or the victim's close relatives as to what the sentence should be are therefore not relevant, unlike the consequence of the offence on them', Practice Direction (Victim Personal Statement) [2002] 1 Cr. App. R. (S) 482.

${ }^{7}$ A good overview of the arguments can be found in I. Edwards, 'The place of victims' preferences in the sentencing of 'their' offenders.' [2002] Crim. L.R. 689.

${ }^{8}$ The very designation of an individual as a 'victim' may give rise to an inherent implication that the allegations made by that person ought to be accepted as the historical truth before the tribunal of fact has arrived at its determination as to the guilt of the accused. See, however, M. Brienen and E. Hoegen, Victims of Crime in 22 European Justice Systems (2000), who argue that the presumption of being a 'non-victim' until the trier of fact has determined otherwise operates to prevent some of the abovenoted substantive rights and interests being protected during the pre-trial and trial stages (p30).

${ }^{9}$ Section 4A(1) of the Criminal Law (Rape) Act 1981, as inserted by section 34, Sex Offenders Act 2001.
} 
like many similar US provisions, ${ }^{10}$ it will only apply in the specific circumstance where the defence is attempting to introduce sexual history evidence. However, any broader, more general role for a victim, which might involve the right of an advocate to intervene in cross-examination, the calling of character witnesses, or the pursuit of reparation from the accused would potentially cause immense structural and normative problems within any adversarial system.

\section{BARRIERS TO VICTIM PARTICIPATION}

\section{Structural Barriers}

One of the major obstacles to victim involvement in the criminal process stems from the bipartisan structure of the adversarial criminal justice system. The trial has been said to centre upon the 'sharp clash of proofs presented by litigants in a highly structured forensic setting, 11 where a heavy onus rests on the parties to produce evidence to substantiate their own case, and to perforate the arguments of their opponent. Without root and branch reform, existing trial structures could not easily be adapted to accommodate the meaningful participation of any third party. Proceedings would undoubtedly become lengthy, awkward affairs - particularly if victim's counsel were to call their own witnesses and spend a considerable amount of time cross-examining others called by either the prosecution or the defence. A whole series of further issues may also be introduced into the trial that would have minimal relevance to the determination of guilt. Indeed, Jorda and de Hemptinne have identified the bipartisan nature of proceedings as being one of the main factors that is likely to obstruct the effective participation by victims at the International Criminal Court. $^{12}$

This bipartisan structure of criminal proceedings dictates that trials are typically characterised by a highly competitive and confrontational atmosphere, which renders

\footnotetext{
${ }^{10}$ Some American states, such as Wisconsin, West Virginia and New Hampshire, allow the attorneys of rape complainants to make representations when questions governing the admissibility of sexual history evidence are being considered by the court. One South Carolina provision is even broader in that it permits representations from a victim's advocate in any type of case where the defendant alleges improper or illegal conduct on the part of the victim as part of his or her defence.

${ }^{11}$ S. Landsman, Readings on Adversarial Justice (1988), 2.

${ }^{12}$ C. Jorda and J. de Hemptinne, 'The Status and Role of the Victim' in A. Cassese, P. Gaeta and J. Jones (eds.), The Rome Statute of the International Criminal Court (2002), 1388.
} 
them fundamentally ill-equipped to address emotional trauma and private conflicts that have arisen as a result of the offence. The entire criminal process is designed to culminate in a confrontational showdown between the prosecution and the accused, and such postures can serve only to deepen the existing conflict. ${ }^{13}$ As William Pizzi has remarked, the adversarial system 'turns witnesses into weapons to be used against the other side. ${ }^{14}$ Their testimony must be shaped to bring out its maximum adversarial effect, ${ }^{15}$ and witnesses are thereby confined to answering questions within the parameters set down by the questioner. The victim is denied the opportunity to relay his own narrative to the court using his or her own words, which seems something of an irony given that logic dictates that such an account should have a key role to play in arriving at the truth. ${ }^{16}$ In practice, counsel in adversarial trials seek to take control of the witness, and use questioning to elicit only those facts which he or she feels should be included. Questions are carefully framed to avoid the witness speaking about anything that counsel feels should be omitted from the testimony. The goal, essentially, is to manipulate witness testimony in such a way that victory is made more likely. ${ }^{17}$ This form of control exercised by advocates over witnesses means that the conflict is entirely removed from the hands of its protagonists. The contest culture of the courtroom is not at all conducive to listening to the accounts of individual witnesses, let alone healing conflicts.

It may also be suggested that, from a due process viewpoint, the involvement of another party in the case could be seen to breach the principle of equality of arms. Since the adversarial system relies so heavily on the delicate balance of power achieved through the clear delineation of roles for the prosecution and defence, the system could be perceived as appearing 'out-of-balance' if another party were involved in the case that could actively work against the interests of the defence. Thaman, for example, has noted the risk that the defence may be significantly

13 D. Frehsee, 'Restitution and the Offender-Victim Arrangement in German Criminal Law: Development and Theoretical Implications’ (1999) 2 Buff. Crim. L. Rev. 235, 236.

${ }^{14}$ W. Pizzi, Trials Without Truth (1999), 197.

${ }^{15} \mathrm{Id}$.

${ }^{16}$ Note also that it is well documented how the structures, rules and advocacy tactics which prevail within the adversary system frequently results in the general obscuring of historical facts. See generally R. Eggleston, 'What is wrong with the adversary system?' (1975) A.L.J. 428; M.E. Frankel, 'The Search for Truth: An Umpireal View' (1975) 123 U. Penn. Law Rev .1031; W. Pizzi, Trials Without Truth (1999); S. Steffen, 'Truth as Second Fiddle: Re-Evaluating the Place of Truth in the Adversarial Ensemble' (1988) 4 Utah L.R. 799.

${ }^{17}$ See eg., M. Stone, Cross-Examination in Criminal Trials (1995). 
undermined if victim's counsel is perceived to be aligning himself or herself closely to the prosecution in some form of 'good cop - bad cop' ploy against the accused. ${ }^{18}$

\section{Normative Barriers}

Just as victims are sidelined in practice during the trial, they are also normatively viewed as outsiders to the criminal hearing. Historically, this was not always the case. Victims once had an active participatory role in criminal proceedings, and were responsible for not only initiating, but also for prosecuting offenders without the assistance of a public prosecutor. As Nils Christie has famously noted, these functions were 'appropriated' by the State, ${ }^{19}$ as the focus of the criminal law shifted from the sphere of private law into a form of public law enforceable by the State.

Various reasons have been mooted for this shift, ${ }^{20}$ but whatever the historical explanations may be, they do not necessarily constitute a rational justification for the continuation of a strict dichotomy in the modern criminal justice system between public and private interests. The structures of the contemporary legal system clearly delineate the separate functions, sanctions and rationales of the criminal and the civil law. Whilst civil law has been widely regarded as the appropriate channel for the resolution of disputes between individuals, the criminal law and its penal sanctions are geared towards protecting the public interest in denouncing and punishing unacceptable behaviour, and not the private interests of individual parties. ${ }^{21}$ Ashworth sees the function of the criminal law as 'to penalise those forms of wrongdoing which...touch public rather than merely private interests. ${ }^{22}$ It is on the basis of this punishment paradigm that the structures and values of the criminal justice system have been largely conceived.

\footnotetext{
18 S. Thaman, 'Europe's New Jury Systems: The Cases of Spain and Russia' (1999) 62 Law \& Contemp. Probs. 233, 244.

${ }^{19}$ N. Christie, 'Conflict as Property’ (1977) 17(1) Br. J. Crim. 1.

${ }^{20}$ See generally, J.H. Langbein, 'The Origins of Public Prosecution at Common Law' (1973) 17 Am. J. Legal Hist. 313; D.J. Seipp, 'The Distinction between Crime and Tort in Early Common Law’ (1996) Bu. L. Rev. 59.

${ }^{21}$ A. Ashworth, 'What Victims of Crime Deserve', paper presented to the Fulbright Commission on Penal Theory and Penal Practice, University of Stirling, September 1992, as cited by M. Cavadino and J. Dignan 'Towards a Framework for Conceptualising and Evaluating Models of Criminal Justice from a Victim's Perspective' (1996) 4(3) Int. Rev. of Victimology 153.

${ }^{22}$ Id.
} 
Conceptually then, victims have no role to play in the modern criminal justice system other than to act as 'evidentiary cannon fodder'. ${ }^{23}$ In contrast to continental systems, discussed below, they have no 'right to be heard', ${ }^{24}$ and are denied any form of proactive participation in the trial since their interests are deemed to fall outside the remit of the criminal trial as a forum for the resolution of the dispute between the State and the accused. Victims have been 'conscripted' into an operational role within the criminal justice system, and are generally treated as its servants or agents. ${ }^{25}$ In the view of criminal law purists, the 'rights' and the 'interests' of the victim should thus be pursued under the civil, as opposed to the criminal law, using the law of tort. Therefore, although many victims may feel as though they are 'owed' a right to exercise a voice in decision-making processes, such as prosecution, reparation and sentencing, the criminal justice system places such rights or interests in a firmly subservient position to the collective interests of society in prosecuting the crime and imposing a denunciatory punishment. ${ }^{26}$

\section{The Purist View}

The supremacy afforded to these collective interests is justified primarily on the basis that crime is harmful to society, and that the penal measures imposed by the court are thereby conceived of as an official denunciation of the offender's wrongdoing. It is also considered vital to sideline the subjective desires of individual victims in order to maintain objectivity, consistency, and hence the overall legitimacy of the criminal justice system. It is thus unsurprising that many purists like Ashworth perceive a real risk in compromising the key values and objectives of the criminal justice system in order to recognise the validity of furthering private interests. ${ }^{27}$ According to Weisstub, their central fear is that 'squatters and anarchists' would 'run wild' in the

\footnotetext{
${ }^{23}$ M. Cavadino and J. Dignan, op. cit. n.21, 155.

${ }^{24}$ J. Spencer, 'Improving the Position of the Victim in English Criminal Procedure' (1997) 31 Israel L. R. 286, 292.

${ }_{25}$ D. Faulkner, op. cit. n.3, p.226.

${ }^{26}$ M. Cavadino and J. Dignan, 'Reparation, Retribution and Rights' (1997) 4(4) Int. Rev. Victimology. 233, 237.

${ }^{27}$ See A. Ashworth, 'Punishment and Compensation: Victims, Offenders and the State' (1986) Oxford Journal of Legal Studies 86; The Criminal Process: An Evaluative Study (1998), 32. Other purist viewpoints are set out by D. Garland, Punishment and Modern Society (1990), 252 and A.Von Hirsh, Censure and Sanctions (1993), 6.
} 
criminal justice system, and that 'ad hoc populism' could 'replace the impersonal rigour of codified and judicially made law. ${ }^{28}$

The problem for the purist viewpoint, however, lies in the fact that whatever the historical explanations for the de facto distinctions between public and private realms of law, the distinction has been artificial since its inception during the Middle Ages. Indeed, a closer look at the actual nature of individual crimes and torts suggests that it is not so easy to neatly separate the public from the private interests. As Smith and Hogan note, crimes, as opposed to torts, can be defined as wrongs which Parliament or the courts have deemed to be 'sufficiently injurious to the public to warrant the application of criminal procedure to deal with them, ${ }^{29}$ but the real issue, as Frehsee contends, is whether such separations of doctrine can 'ultimately be found in the measure of whether our stated aims and purposes have been achieved in practice. ${ }^{30}$ Civil and criminal liability are each based on overlapping concepts of fault and recklessness and strict liability, ${ }^{31}$ and many crimes have their equivalent in the law of tort. $^{32}$ As Weisstub has argued, public and private wrongs may be conceived as variations along the same continuum of fault, ${ }^{33}$ a theoretical blurring already reflected in a number of ways on both the domestic and international platforms.

\section{The Merging of Public and Private Interests}

Over the course of the past three decades, the concept of victim / offender restitution has made significant inroads into the criminal law. In their examination of the Race Relations (Amendment) Act 2000, Field and Roberts argue that a 'subtle but important shift' has taken place, whereby the criminal justice system is becoming increasingly geared 'toward a more interactive relationship between the individual rights of victims and their families on the one hand, and collective interests on the

\footnotetext{
${ }^{28}$ D. Weisstub, 'Victims of Crime in the Criminal Justice System' in E Fattah (ed), From Crime Policy to Victim Policy (1986), p205.

${ }^{29}$ J.C.Smith and B. Hogan, Criminal Law (2002), p17.

${ }^{30}$ D. Frehsee, op. cit. n.13, 243.

${ }^{31}$ A. Goldstein , 'Defining the Role of the Victim in Criminal Prosecution' (1982) 52 Miss.L.J 515, 530.

${ }^{32}$ L. Sebba, 'Will the 'victim revolution' trigger a reorientation of the criminal justice system?' (1997)

1(3) Israel. L. Rev. 379, 399.

${ }^{33}$ D. Weisstub, op. cit., n.28, p206.
} 
other. ${ }^{34}$ Since 1972, criminal courts have been empowered to order an offender to pay a victim compensation for 'any personal injury, loss or damage resulting from the offence, ${ }^{35}$ and criminal courts are now obliged to consider whether it would be desirable to make a compensation order and must give reasons for refusing to do so. ${ }^{36}$ So too, the explosion in restorative justice initiatives has presented victims with much greater opportunities to seek reparation directly from the offender. In the last decade, such projects have become widespread and have been placed on some form of a statutory footing in many jurisdictions. ${ }^{37}$

This apparent breakdown in the public / private divide has not been confined to the domestic arena. Advances in human rights and criminal justice discourses on the international platform have guaranteed victims of 'non-state' crime similar human rights safeguards as the more 'conventional' victims of abuse of state power. A key theme to have evolved in international human rights discourse in recent years is that the State has a duty to enforce domestic criminal sanctions against offenders, thus severely curtailing the level of prosecutorial discretion in determining which crimes to prosecute. $^{38}$ In many international criminal justice systems and human rights fora, 'victims' rights' are therefore increasingly being construed as a form of human rights, worthy of legal protection within domestic systems. ${ }^{39}$ Perhaps even more significant in the context of this article is that these norms grant victims certain participatory rights in criminal proceedings, overreaching the purist delineation of the functions of criminal and civil law. For example, the United Nations Declaration of Basic Principles of Justice for Victims of Crime states that judicial and administrative processes should allow 'the views and concerns of victims to be presented and considered at

\footnotetext{
${ }^{34}$ S.Field and P. Roberts, 'Racism and Police Investigations: Individual Redress, Public Interests and Collective Change after the Race Relations (Amendment) Act 2000' (2002) 22(4) L. S. 493, 495. The Act provides for remedies for victims of racial discrimination in criminal investigations.

${ }^{35}$ The court may make a compensation order, instead of, or in addition to, any other penal sanction. Where the offender has insufficient means to pay both, the court shall give preference to the compensation order (section 130(12) Powers of Criminal Courts (Sentencing) Act 2000). The powers were originally set out in Criminal Justice Act 1972.

${ }^{36}$ Section 130, Powers of Criminal Courts (Sentencing) Act 2000. Section 130(4) of the Act states that compensation 'shall be of such amount as the court considers appropriate, having regard to any evidence and to any representations that are made by or on behalf of the accused or the prosecutor, the Court.'

${ }^{37}$ For an international overview, see D. Roche, Accountability in Restorative Justice (2003), Chapter 1.

${ }^{38}$ See generally A. Mowbray, The Development of Positive Obligations under the European Convention on Human Rights by the European Court of Human Rights (2004).

${ }^{39}$ J. Doak, 'Victims and the Criminal Process: an analysis of recent trends in regional and international tribunals' (2003) L.S. 1; F. Klug, (2004) 'Human Rights and Victims' in E. Cape (ed), Reconcilable Rights? Analysing the Tension between Victims and Defendants (2004).
} 
appropriate stages of the proceedings where their personal interests are affected. ${ }^{40}$ Given that the accused has a right to counsel in many international human rights instruments, ${ }^{41}$ it could be argued that the principle of 'equality of arms' requires that complainants should be afforded similar protection before the courts. This theme was highlighted by a recent UN working paper that stated:

'Looking at the rights of victims as a whole, the right to counsel seems the logical complement of the defendant's right to counsel. There is no zero-sum game between those two rights. The victim's right to be treated with respect seems to have little if any negative implications for the offender. ${ }^{42}$

The provisions of the Rome Statute permit victims at the International Criminal Court to choose their legal representatives, who have a right to present their views and make submissions when their interests are likely to be affected. ${ }^{43}$ Such views and submissions may be made at all stages of the court proceedings with only the limitation that it would not be prejudicial or inconsistent with the rights of the accused. ${ }^{44}$ In an era where globalisation and harmonisation of criminal procedure seems set to continue indefinitely, it is inevitable that domestic processes and policymakers and criminal justice agencies will be increasingly influenced by such international developments.

\section{STRANGE BEDFELLOWS: VICTIMS AND PUBLIC PROSECUTORS}

Whilst it is clear that the rise of the victim agenda has affected the formulation of policy and the direction of criminal justice discourse in both the domestic and international contexts, its impact has been limited in most common law systems. In the adversarial system of England and Wales, the victim's interests in criminal trials have traditionally been subsumed by the broader 'public' interest which is, in theory, safeguarded by the prosecution. However, there are nonetheless clear signs that the

\footnotetext{
${ }^{40}$ UN Doc A/40/53 (1985). GA Res 40/43, para 6(b).

${ }^{41}$ See, eg Article 6(3)(c) ECHR; Article 14(3)(d) ICCPR; Basic Principles on the Role of Lawyers, Principle 8.

${ }^{42}$ United Nations, Offenders and Victims: Accountability and Fairness in the Criminal Justice Process, UN Doc A/ CONF.187/8 (1999), para 21.

${ }^{43}$ See Article 68, Rome Statute.

${ }^{44}$ Article 68(1). Many commentators are, however, sceptical of the potential effectiveness of these mechanisms. See further C. Jorda and J. de Hemptinne, op. cit. n.12, 1401.
} 
conceptual collapse of the public / private divide has encouraged both the Crown Prosecution Service and the General Council of the Bar to undertake a number of initiatives aimed at forging a much closer relationship between prosecutors and victims. Such initiatives would appear to be founded on the assumption that, if prosecutors were to assist the victims in their preparation for testifying, this could alleviate some of the stress associated with testifying and in turn lead to better evidence. ${ }^{45}$ However, in addition to heightening the potential for conflicts of interest, the path of reform has been uncertain and its ultimate destination is still undetermined.

Traditionally, Crown prosecutors have not been obliged to represent the interests of the victim. Instead, they have been expected to exercise a broad discretion, strongly rooted in the public interest, in determining the extent to which the wishes of the victim should influence both the charging decision and the conduct of the case at court. The victim / prosecutor relationship has nonetheless undergone a significant change over the course of the past decade. In 1993 the Crown Prosecution Service published its Statement on the Treatment of Witnesses and Victims and declared its intent to make 'provision for the proper care and treatment of victims and witnesses... an essential part of CPS initiatives'. Prosecutors were obliged inter alia to take into account the interests of victims and witnesses in any decision to prosecute; inform the court where the victim has made a claim for compensation; try to help victims and witnesses at court by giving 'appropriate and useful information'; introduce themselves to witnesses; look after the interests of the witnesses as the trial progresses; and to explain the results of cases, whenever possible, to victims at court. Following recommendations made by Sir Iain Glidewell in his review of the Service in $1998,{ }^{46}$ and similar recommendations contained in Sir William Macpherson's report into the death of Stephen Lawrence, ${ }^{47}$ the CPS has assumed responsibility for communicating and explaining decisions to drop or alter charges directly to victims rather than via the police.

\footnotetext{
${ }^{45}$ Home Office, Achieving the Best Evidence in Criminal Proceedings: Guidance for Vulnerable and Intimidated Witnesses, Including Children (2001).

${ }^{46}$ Sir I. Glidewell, Review of the Crown Prosecution Service, Cmnd 3960 (1998).

${ }^{47}$ Sir W. MacPherson, (1999) The Stephen Lawrence Inquiry: Report of an Inquiry by Sir William MacPherson of Cluny. Cmnd 4262 (1999).
} 
One of the most notable areas of reform relates to the degree of contact victims ought to have with prosecutors prior to the trial. Although the Code of Conduct of the Bar of England and Wales prohibits barristers from discussing the evidence in the case with witnesses, ${ }^{48}$ it was altered in 1995 to permit barristers to introduce themselves to witnesses prior to the trial. ${ }^{49}$ More recently, the role of the prosecution has also expanded so that pre-trial meetings can now be accommodated in cases involving vulnerable witnesses eligible under the Youth Justice and Criminal Evidence Act in order to 'to establish a link between the CPS and the witness and provide witnesses with reassurance that their needs will be taken into account. ${ }^{50}$ Where prosecutors believe that the witness may be eligible for special measures under the Youth Justice and Criminal Evidence Act 1999, meetings are now arranged prior to the trial in order to determine which measure(s) should be the subject of an application to the court. However, the parameters of such meetings are stringently set: their purpose is solely to determine whether the quality of a witness's evidence might be improved by a Special Measures Direction under the Act. It is still clear from the Home Office / CPS guidance that any substantive issues relating to the evidence must not be discussed:

'It is imperative that there is no discussion whatsoever with the witness as to the evidence in the case. It is quite possible that the witness will wish to mention or discuss a matter relating to evidence but both the Bar Code of Conduct and the Guide to the Professional Conduct of Solicitors make it clear that there must be no discussion of evidence with the witness. Any such discussion would be likely to lead to an allegation of rehearsing or coaching of the witness...If the witness does wish to discuss an evidential matter, the prosecutor must explain that the witness must discuss his or her evidence with the police officer, not the prosecutor, and that arrangements for this to happen can be made. ${ }^{, 51}$

The rules regulating pre-trial contact are now set to be unravelled still further. Following the report by the Director of Public Prosecutions into issues arising out of the Damilola Taylor murder trial, ${ }^{52}$ the Attorney General issued a Consultation Paper

\footnotetext{
${ }^{48}$ See para 6.3.1 of the Code of Conduct. Lay client, character and expert witness are exempt.

${ }^{49}$ The change followed a recommendation from the Royal Commission of Criminal Justice that the rule whereby prosecution barristers were prohibited from having any contact whatsoever with witnesses to the fact should be relaxed (Royal Commission on Criminal Justice, Report, Cmnd 2263 (1993), para 50).

${ }^{50}$ Home Office, Early Special Measures Meetings between Crown Prosecutors and Vulnerable or Intimidated Witnesses (2001).

${ }^{51}$ Id., paras 23-24.

${ }^{52}$ The full findings of the CPS inquiry were never published, although a summary was given through a press release. One of these issues concerned the extent to which the CPS should have been able to
} 
considering whether or not prosecutors should be permitted to interview prosecution witnesses before trial. ${ }^{53} \mathrm{~A}$ response to the consultation was issued in December $2004,{ }^{54}$ and confirmed radical reform to the rules governing pre-trial contact was indeed on the horizon.

The Attorney General concluded that professional rules should be altered to enable prosecutors to conduct pre-trial interviews where they consider them necessary to confirm the reliability of a witness's evidence, or to clarify the evidence which the witness can give. It was envisaged that the major benefits of such interviews would include 'enabling prosecutors to form better prosecution decisions, to clarify issues and to make witnesses more comfortable with the trial process. ${ }^{55}$ Although the Attorney-General acknowledged concerns expressed by a number of bodies over the risks of coaching and of potential blurring of the investigative and prosecutorial elements of the criminal process, ${ }^{56}$ he considered that training for prosecutors, coupled with 'detailed guidance' contained in the Code of Practice, would be sufficient to safeguard against such concerns. ${ }^{57}$

The long-standing practice of not discussing evidence with witnesses in England and Wales will thus be discontinued, and as such the Bar's Code of Conduct will have to be amended in the near future. ${ }^{58}$ It remains to be seen how widely prosecutors will make use of the new discretion to interview witnesses, although it can probably be assumed that such meetings will be the exception, rather than the norm, and as such

conduct interviews with a 12 year-old girl, known as Bromley, in preparation for her evidence. The DPP's inquiry expressed regret that the prosecution was very limited in its ability to investigate the witness's story in advance of the trial, and the inquiry concluded that the possibility of changing the rules to allow for such meetings should be given careful consideration.

${ }^{53}$ Crown Prosecution Service, Pre-trial Witness Interviews by Prosecutors: A Consultation Paper (2003).

${ }_{54}^{54}$ Lord Goldsmith QC, Pre-Trial Witness Interview by Prosecutors: Report (2004).

${ }^{55}$ Id., p13.

${ }^{56}$ See eg., Criminal Bar Association, Response to 'Pre-Trial Witness Interviews by Prosecutors, A Consultation Paper (2003); Liberty's Response to the CPS Consultation on Pre-Trial Interviews (2003). For a closer examination of the issue surrounding 'coaching' of witnesses, see J. Grohovsky, 'Giving Voice to Victims: Why the Criminal Justice System in England and Wales Should Allow Victims to Speak Up for Themselves' J. Crim. L. 416.

${ }^{57}$ Id., p20.

${ }^{58}$ At the time of writing, a working group is currently being established to consider how best to pilot the proposals. Discussions are also to be held with the professional bodies to consider how best to implement changes to their codes of conduct. 
are unlikely to alter dramatically the perception held by many victims that they are 'outsiders' to the legal process.

\section{The Limitations of the Victim / Prosecutor Relationship}

While the increased recognition of the needs facing victims and witnesses by the CPS is to be welcomed, there are clear limits as to how far the rapport can be stretched. It is has been a traditional maxim of common law systems that the duty of prosecuting counsel is not to obtain a conviction at all costs but to act instead as a 'minister of justice'. ${ }^{59}$ There is an inherent tension in the idea of an objective 'minister of justice' presenting evidence to the court dispassionately as part of the overall public interest in pursuing a conviction, whilst at the same time performing any sort of support or protective function in relation to the victim. Indeed, empirical evidence would seem to reflect the view that prosecutors are fundamentally unable to effectively take into account the private interests of the victim whilst pursuing the public interest in the prosecution. Research suggests that practice is still variable on the extent to which barristers introduce themselves to complainants before trial. ${ }^{60}$ Many victims continue to feel as though prosecutors are uninterested in their cases and that their interests are poorly represented in the court proceedings. ${ }^{61}$ Prosecutors are also perceived as being less vigorous or energetic in the manner in which the case was presented, but it is worth noting that even those who do strive to secure a conviction are clearly limited in their ability to conduct their case with the same degree of zeal as that of the defence. $^{62}$

\footnotetext{
${ }^{59}$ See, for example, $R v$ Banks [1916] 2 K.B. 621, where the court held, citing $R v$ Puddick (1865) 4 F. \& F. 497, 499, that 'prosecuting counsel should regard themselves as ministers of justice assisting in its administration rather than advocates'.

${ }^{60}$ See J. Temkin, (2000) "Prosecuting and Defending Rape: Perspectives from the Bar" 27(2) Journal of Law and Society 219; HM Crown Prosecution Service Inspectorate, A Report on the Joint Inspection into the Investigation and Prosecution of Cases Involving Allegations of Rape (2002), para 11.34; Lord Goldsmith QC, Pre-Trial Witness Interviews by Prosecutors: Report (2004).

61 J. Shapland, J. Willmore, and P. Duff, Victims in the Criminal Justice System (1985); G. Chambers and A. Millar, Prosecuting Sexual Assault (1986); Victim Support, Women, Rape and the Criminal Justice System (1996); Audit Commission, Victims and Witnesses - Providing Better Support (2003); Northern Ireland Statistics and Research Agency, Victims' and Witnesses' Views on their Treatment in the Criminal Justice System (2004).

${ }^{62}$ For example, there are evidential rules that impede the scope of the prosecutor's cross-examination of the accused. Admission of evidence regarding previous convictions or bad character of the accused will only be permitted in very particular circumstances under section 101 of the new Criminal Justice Act.
} 
It is, however, the stress of giving testimony that is one of the most significant factors in secondary victimisation. It is well documented that witnesses frequently report feeling harassed and badgered under cross-examination, particularly in cases of rape or sexual assault. ${ }^{63}$ The character of such victims is frequently called into question, and cross-examiners will deploy a range of linguistic tricks in an attempt to 'trip up' the witness. ${ }^{64}$ It is at this point in proceedings that the inadequacy of the victim / prosecutor relationship manifests itself most clearly. In their survey of Scottish sexual offence trials, Brown et al found that prosecutors will avoid frequent objections to shield the witness from such character attacks, since too many interventions are not regarded as tactically astute. ${ }^{65}$ It is broadly acknowledged amongst practitioners that too many objections make a jury suspicious and they may want to know what counsel is trying to hide. ${ }^{66}$ Besides, a physically distressed witness suffering at the hands of an overly zealous cross-examiner for the defence could play into the hands of the prosecution by winning the jury's sympathy for the victim and alienating the defence. In particular, there is evidence to suggest that some prosecutors believe that the appearance of a visibly distressed child witness may make a jury more likely to convict. ${ }^{67}$ Thus, in most cases, it would seem that the prosecutor will only object to such questioning if it is strategically advantageous to do so.

Few would dispute the idea that prosecutors ought to exercise courtesy and respect whilst dealing with victims, but it is not clear whether the adversarial structures of the criminal hearing, or indeed the public interest which underpins criminal prosecutions could accommodate any expansion in the role of the Crown Prosecution Service. Ultimately, it would seem that the imposition of additional duties and responsibilities on Crown prosecutors is unlikely to be an effective means of safeguarding the interests and rights of victims. The structural parameters of the trial dictate that the victim has no right to ensure that his or her voice is heard. Even where the victim does testify, his or her words are limited in that he or she must only respond to the

\footnotetext{
63 See S. Lees, Carnal Knowledge: Rape on Trial (1996); Victim Support, op. cit. n.61.

${ }^{64}$ See L. Ellison, The Adversarial Process and the Vulnerable Witness (2001), 94-98.

${ }^{65}$ B. Brown, M. Burman, and L. Jamieson, (1992) Sexual History and Sexual Character Evidence in Scottish Sexual Offence Trials, 56.

${ }^{66}$ See generally, J. Glissan and S. Tilmouth, Advocacy in Practice: Being the Third Edition of Cross Examination: Practice and Procedure (1998), 169.

67 Australian Law Reform Commission, Children's Evidence: Closed Circuit Television, Report 63 (1992), para 14.105.
} 
questions posed by counsel, and has no right to respond directly where his or her character is attacked by the defence. From the victim's perspective, he or she is largely denied the opportunity of explaining consequences of an offence directly to the court. ${ }^{68}$ This raises serious issues not only in respect of the extent to which the system can be responsive towards protecting the rights and interests of victims, but also in relation to the truth-finding potential of the adversarial mode of trial. It might therefore be asked whether the victims or their legal representatives ought to be able to exercise a right of allocution within the criminal trial. This would save the prosecutor from having to juggle two roles which are ultimately incompatible. The inquisitorial systems of continental Europe may provide a useful insight into how such a mechanism could work.

\section{THE VICTIM AS A TRIAL PARTICIPANT: THE INQUISITORIAL \\ EXPERIENCE}

Although there is no such thing as a 'prototype' inquisitorial system, most European criminal justice systems are regarded as non-adversarial as they place little emphasis on party control. Many make some sort of formal provision for the participation of the victim within, and indeed beyond, the trial process. Questions concerning the punitive aspects of the criminal process are not divorced from the reparative elements of the civil process. The same set of facts thus gives rise to a unitary process, which seeks to uphold the rights and interests of the State, the victim and the accused. Many continental jurisdictions permit victims to join the criminal action instituted by the State as 'subsidiary prosecutors' or, through using a partie civile or 'adhesion' procedure. $^{69}$

For example, in Germany, victims of certain serious offences or the relatives of a murder victim may act as subsidiary prosecutors (Nebenkläger).$^{70}$ A lawyer is often

\footnotetext{
${ }^{68}$ Note that Victim Personal Statements, referred to above, are not released to the jury and may only be used for the purposes of sentencing.

${ }^{69}$ It is ironic however, that unlike the English common law systems, continental systems do not generally permit victims to pursue their own private prosecutions. Some, including France and Belgium, do permit the victim to set the prosecution process in motion where the ministère publique has declined to do so, through issuing a summons for the accused to appear in court. Once this occurs, however, the public prosecutor must take over (M. Brienen and E. Hoegen, op cit. n.8, 1066-1067).

${ }^{70}$ Id., 364;
} 
appointed for this purpose, although the cost will be borne by the complainant unless the accused in convicted. ${ }^{71}$ The victim is entitled to certain active participatory rights, including the right to be present at all stages of the process; to put additional questions to witnesses; to provide additional evidence / make a statement; or to present a claim for compensation. The procedure thereby recognises the special status of the complainant as the alleged victim of the criminal offence, whilst acknowledging at the same time the normative role of the state in prosecuting crime. Thus the public prosecutor retains the burden of preparing and presenting the prosecution, and there is no official relationship with the auxiliary counsel.

Although some form of subsidiary prosecution has been an avenue open to victims in Germany since 1924, it had fallen into virtual disuse until the rise of the victim on the policy agenda in the 1980's. ${ }^{72}$ A survey by Kaiser et al conducted in 1989/90 found that subsidiary prosecutors participated in $14.3 \%$ of cases, ${ }^{73}$ and tended to play a predominantly passive role, only intervening occasionally to request that additional evidence be taken or to appeal against procedural decisions. ${ }^{74}$ However, where victims did make use of the facility, most felt it had a positive effect upon their position within the system. ${ }^{75}$

Erez and Bienkowska evaluated the operation of a similar subsidiary prosecution scheme in Poland, where the researchers found that over a third of victims (36\%) whose cases went to trial acted as subsidiary prosecutors. ${ }^{76}$ However, the survey also found that the main reason mentioned by victims for not exercising this privilege was that no one had informed them of this right (49\%). ${ }^{77}$ As with those victims who had

\footnotetext{
${ }^{71}$ R. Juy-Birmann, 'The German System' in M. Delmas-Marty and J. Spencer (eds), European Criminal Procedures (2002), 302.

${ }^{72}$ A. Sanders, Taking Account of Victims in the Criminal Justice System: A Review of the Literature (1999), p12.

${ }^{73}$ M. Kaiser, 'The Status of the Victim in the Criminal Justice System According to the Victim Protection Act' in G Kaiser, H Kury and H-J Albrecht (eds), Victims and Criminal Justice: Legal Protection, Restitution and Support (1991), p604.

${ }^{74}$ Id., 605.

${ }^{75}$ Id., 602.

${ }^{76}$ E. Erez and E. Bienkowska, 'Victim Participation in Proceedings and Satisfaction with Justice in the Continental Systems: The Case of Poland' (1993) 21 Journal of Criminal Justice 47, 50. Note, however, that Andrew Sanders has suggested that this figure is 'misleadingly high' since there was a relatively low response rate to the survey (A. Sanders, op. cit. n.72, 13).

${ }^{77}$ Id., 50.
} 
prosecuted offences privately, higher satisfaction rates were recorded for those victims who acted as subsidiary prosecutors than for those who did not. ${ }^{78}$

Although the procedure has the potential to help ease the plight of victims testifying in criminal proceedings, it is clearly underdeveloped in both Germany and Poland. Kury and Kaiser reported that $28.6 \%$ of victims stated that they would have liked to have participated in the trial had they been made aware of their right to do so, and it would seem that, in general, victims in Germany are ill-informed of their rights to participate as subsidiary prosecutors. ${ }^{79}$ In one survey, a quarter of prosecutors stated that they 'never' informed victims of their rights, and only one in ten stated that they 'always' made such information available, as they are required to do under the law. ${ }^{80}$ Most prosecutors stated that their duty to give such advice was 'quite simply forgotten' or that 'there was no suitable opportunity' to do so. ${ }^{81}$ The researchers concluded that the majority of judges and lawyers retained a negative attitude towards the procedure which they were unwilling to change. ${ }^{82}$

A more optimistic picture of the subsidiary prosecution procedure in Germany was presented by Bacik et al. The authors found that the procedure was used widely where the complainant is a victim of rape or sexual assault; it was estimated that up to $50 \%$ of these complainants may make use of it. ${ }^{83}$ However, while all those interviewed agreed that it could be psychologically helpful for the victim to have his or her own lawyer present during the trial, the researchers did express some concerns that, in many cases, the victim's lawyer merely duplicated the role of the prosecution. ${ }^{84}$

The empirical research from continental jurisdictions would seem to suggest that, while many victims would like to play such a role in the trial, they are regularly prevented from doing so by the reluctance of the legal profession to advise victims of

\footnotetext{
${ }^{78}$ Id., 51.

${ }^{79}$ H. Kury and M. Kaiser, 'The Victim's Position within the Criminal Proceedings - An Empirical Study' in G Kaiser, H Kury and H-J Albrecht (eds), Victims and Criminal Justice: Legal Protection, Restitution and Support (1991).

${ }^{80}$ H. Kury, M. Kaiser and J.R. Teske, 'The Position of the Victim in Criminal Procedure - Results of a German Study’ (1994) 3 Int. Rev. Victimology 69, 75.

${ }^{81}$ Id.

${ }^{82}$ Id., 76.

${ }^{83}$ I. Bacik, C. Maunsell and S. Grogan, The Legal Process and Victims of Rape (1998), pp68. ${ }^{84}$ Id.
} 
their rights and push forward the interests of the victim proactively. The main reason for this is that '[j] udges and prosecutors still regard the victim predominantly in his or her role as a witness, whereas the victim wants to be regarded as a party to the proceedings. ${ }^{85}$ Unlike the bipartisan nature of the adversarial trial, the structural framework of the inquisitorial system would facilitate a proactive role for the victim without much difficulty. The problem with the procedure is thus essentially an attitudinal one: victims are still perceived as outsiders to the criminal hearing. Bacik et al suggest that the victim is often conceived as some sort of 'assistant' to the prosecutor, ${ }^{86}$ which could prove extremely problematic where the interests of the victim and the prosecution diverge.

\section{The Adhesion / Partie Civile Procedure}

One possible way of sidestepping the particular difficulty highlighted by Bacik et al may be to accommodate the victim's counsel as an individual party to the proceedings, distinct from the prosecution, and capable of exercising a protective role within the trial whilst at the same time pursuing a reparative claim. An alternative model which allows for this is commonly referred to as the 'adhesion' or 'partie civile’ procedure.

Participation of the victim as an independent civil party bears some similarity to the subsidiary prosecution model, although it has a distinct advantage in that it acknowledges the victim's status as a separate party to the trial. The procedure is relatively commonplace in France and Belgium, where the victim must formally demonstrate his or her intention of becoming a party to the proceedings by initiating an independent action before the juge d'instruction (constitution de partie civile) at any stage in the proceedings. ${ }^{87}$ The procedure confers three important rights upon victims of crime. First, they can use the procedure to initiate a prosecution; secondly, they have the right to participate and be heard as a party in any prosecution; and thirdly, they have a right to pursue a claim for civil damages in the criminal action. ${ }^{88}$

\footnotetext{
${ }^{85}$ H. Kury and M. Kaiser, op. cit. n.76, 606.

${ }^{86}$ I.Bacik et al, op. cit. n.83, p68.

${ }^{87}$ Sebba cites a 1991 survey which found that it was regularly used by a third of victims (L. Sebba, op. cit. n.32, 406).

${ }^{88}$ R.S. Frase, 'Comparative criminal justice as a guide to American law reform: how do the French do it, how can we find out and why should we care?’ (1990) 78(3) Cal. L. Rev. 538.
} 
However, while there is evidence to suggest that parties do exercise the right to be heard and pursue civil claims, it appears that victim-initiated prosecutions in France are rarely invoked and depend heavily on the discretion of the examining magistrate. ${ }^{89}$ From the outset of proceedings, the victim can insist that the examining magistrate investigates and documents in the dossier any civil claim for damages. Participation within the trial tends to be limited to the pursuit of the civil claim, although the partie civile (or their legal representative) has the power to examine witnesses and make submissions relevant to the defendant's guilt. He or she also has a right to give a closing argument, although no intervention is possible while the victim is undergoing questioning. ${ }^{90}$ Various appeal mechanisms are also open to victims where the judgment has negatively affected their civil interests. ${ }^{91}$ Similarly, the German 'adhesion' procedure, distinct from the subsidiary prosecution described above, confers similar participatory rights to the victim and also makes it possible for civil damages to be claimed within the criminal action. ${ }^{92}$ A civil claim may be made through notifying the clerk of the court: it is not necessary for victims to attend the trial or be legally represented. ${ }^{93}$

\section{Potential Benefits of Participation}

This sort of participation should, in theory, reap benefits both for victims and for the criminal justice system more generally. The ability to pursue civil damages in the criminal trial should, in theory, improve speed, cost and time involved given that both civil and criminal issues are resolved in the same forum. In addition to improved efficiency of both the criminal and civil justice systems, there are a number of advantages that would be specific to the complainant. Under a unitary system, the civil party can have a 'free ride' on the evidence at the criminal trial, ${ }^{94}$ which should guarantee victims some tangible or symbolic compensation. ${ }^{95}$ The victim would not, therefore, have to testify again under stressful adversarial conditions in order to obtain

\footnotetext{
${ }^{89}$ Id., 615..

${ }^{90}$ Bacik et al., op. cit. n.80, 59.

${ }^{91}$ C. Jorda and J. de Hemptinne, op. cit. n.12, 1401.

${ }^{92}$ Sections 403-406, Stafprozeordnung [Criminal Code].

${ }^{93}$ M. Kaiser and M. Kilchling, 'Germany’ in D. Greer (ed.), Compensating Crime Victims (1996), 265.

${ }^{94}$ R. Lerner, (2001) 'The Intersection of Two Systems: An American on Trial for an American Murder in the French Cour d'Assises' (2001) U. Illinois L. Rev. 791, 815.

95 Providing, of course, that the accused is found guilty. Furthermore, the actual amount of compensation seems to be a secondary concern of many victims, who seem more concerned about whether the offender has made a personal contribution to the compensation. See J. Shapland et al., op. cit. n.61, 67.
} 
full compensation in the civil courts. ${ }^{96}$ Bacik et al noted a number of key advantages for complainants in the rape cases they observed. The researchers found that participants with some form of legal representation experienced fewer difficulties in obtaining information about case developments; had a clearer understanding in relation to their role at trial; reported higher levels of confidence and articulateness when testifying; experienced less hostility from the accused's lawyer; and were much more satisfied with their overall treatment within the legal process. ${ }^{97}$ It would therefore appear that offering victims some form of acknowledged and formal role at the trial should enhance their sense of satisfaction with the criminal justice system, and serve to combat the sense of powerlessness that many have reported during criminal proceedings. ${ }^{98}$ In turn, more victims might be encouraged to report crimes and co-operate with the police and prosecution authorities.

Aside from these specific benefits to victims, there are conceivable advantages for the criminal justice system as a whole. Victim involvement in the trial could also provide an important contribution to the wider values of criminal justice, in promoting truthfinding in criminal proceedings. It is ironic that the person whose complaint was instrumental in bringing the case to court is denied the right to participate as a separate player in proceedings, but must instead play an extremely limited role in so far as they may only testify if called by the prosecution, and may only relay information to the factfinder within the questioning parameters laid down by counsel. As the alleged victim of the offence, it would seem logical that the complainant is best placed to give an account of the circumstances of the offence in his or her own words, notwithstanding more general problems of witness testimony such as vagaries of memory and the fact that not all complainants may tell the truth. ${ }^{99}$ The injection of

\footnotetext{
${ }^{96}$ Even if a victim does pursue compensation through the civil courts, the vast majority of offenders will have very limited resources and so would be unable to pay out damages which victims may seek, particularly for serious offences against the person. Greer has noted that one of the main reasons for the establishment of state compensation schemes was the inability of victims to obtain compensation directly from offenders. He argues that, overall, the 'amount of compensation... obtained by victims of crimes of violence through the criminal process in one form or another appears to be comparatively modest.' (D. Greer, Compensation for Criminal Injury (1990), 221.

${ }^{97}$ I. Bacik et al., op. cit. n.80.

${ }^{98}$ See also H. Kury and M. Kaiser, op. cit. n.76; Erez and Bienkowska, op. cit. n.73. (pp39-40). A study of victims in the Dutch criminal justice system has also suggested that many victims feel that procedures which even allow passive participation in the criminal trial carry a certain symbolic importance for many victims which, in turn, can reduce feelings of exclusion and unfairness (J. Webbers, 'Victims in the Dutch Criminal Justice System' (1995) 3 Int. Rev. Victimology 323, 339).

${ }^{99}$ C. Jorda and J. de Hemptinne, op. cit. n.12, 1400.
} 
the victim's perspective could lend additional transparency to the outcome of the case, and, as Telford and Walker point out, the broad notion of participation as a basic value of the criminal justice system could serve to enhance its overall legitimacy:

'Participation is clearly an important concept in criminal justice as an instrument for assisting in the achievement of other ultimate objectives. For example, without the involvement of the public in reporting crime the criminal justice system would be fatally handicapped in its pursuit of the security objective. Similarly, participation in the criminal process also serves to legitimise the system by engaging interested, and often aggrieved parties in resolving a dispute, or as a form of external audit to help ensure equitable procedures... [T] The concept of participation, in the sense of involvement in the public life of the community and polity with the sense of dignity and personal respect which this brings, is also a good in itself. Furthermore, insofar as there is a non-state or informal sector in criminal justice, participation is a key good in this context also, again both as a means of securing other key objectives and in its own dignitarian terms. ${ }^{100}$

Similarly, Weisstub has argued that the civil justice system could also benefit from 'infusing itself' with the symbolism of criminal sanctions, thereby showing itself to be 'consonant with public morality and conscience. ${ }^{101}$ There are also various economic arguments that could be used in support of this view: reparative sentences significantly lessen the financial burden on the taxpayer and a corresponding reduction in separate civil claims could reduce litigation in the courts. ${ }^{102}$

In spite of the apparent advantages that a participatory model of criminal justice may bring, it seems that practitioners in at least some inquisitorial countries are reluctant to grapple with the inevitable complexities that arise from a procedure that attempts to resolve both civil and criminal issues in a unitary action. Kaiser and Kilchling have reported that the adhesion procedure is 'very unusual', and suggest while it is widely recognised, it attracts insufficient legal fees for attorneys and a majority of jurists regarded it as an 'alien body' within criminal procedure. ${ }^{103}$ Similarly, Frehsee has noted:

\footnotetext{
${ }^{100}$ N. Walker and M.Telford, Designing Criminal Justice: The System in Comparative Perspective, Report 14, Review of the Criminal Justice System in Northern Ireland (2000), p10.

${ }^{101}$ D. Weisstub, op. cit. n.28, 207.

${ }^{102}$ L. Zedner, 'Reparation and Retribution: Are they Reconcilable?’ [1994] M.L.R. 228, 233.

${ }^{103}$ Id., 561.
} 
'Lawyers who specialise in criminal law do not like to deal with civil law matters; they do not like to be misused as civil executory officers... [T] procedure is not routine; its management and control are rather awkward and ineffective. $^{104}$

The lack of a contest-based structure in inquisitorial trials should mean that, in theory, there should be few difficulties in accommodating direct input from victims in the trial as compared with the severe logistical difficulties that would be encountered in attempting to integrate the procedure into an adversarial framework. The fact that inquisitorial proceedings are judge-led, as opposed to party-led, indicates that the participation of a third party would be much less problematic, and would be much less likely to be seen as a factor that could potentially endanger the equality of arms.

Unfortunately, the theoretical potential of the inquisitorial system to accommodate the victim as a party to proceedings is partly impeded by the way in which systems of participation operate in practice. There appears to be an institutional reluctance to use and develop such procedures so as to bring tangible benefits to victims. The structural potential for victim involvement in continental trials has been quelled by the values and working cultures of the legal profession. Victims are still viewed as outsiders to the criminal process in many inquisitorial jurisdictions; as Brienen and Hoegen report, their interests are as still widely viewed as 'strongly subordinate' to the determination of the offender's guilt. ${ }^{105}$ In both the adversarial and inquisitorial systems, practitioners and policymakers appear reluctant to alter, develop or resource procedures that are capable of giving the victim a greater role at the trial. The orthodox conception of the criminal trial as a public forum dominated by the State prevails in both systems, and this representation has severely constrained the potential for victim participation.

\section{CONCLUSIONS}

There is much that can be learnt from continental systems concerning the type of structures that would need to be put in place before the victim could participate

\footnotetext{
${ }^{104}$ D. Frehsee, op. cit. n.13, 242.

${ }^{105}$ M. Brienen and E. Hoegen, op. cit. n.8, 1069. Brienen and Hoegen made similar findings in relation to Austria. Turkey and Greece.
} 
effectively within a criminal hearing. There is, however, an obvious disparity between legal rules and actual practices in the continental systems where participation mechanisms already exist. Thus even if the structures and processes of the criminal justice system were to continue their current drift into uncharted inquisitorial waters, the attitudes of criminal law purists and the working culture of the Bar could still act as significant barriers to meaningful participation by victims in criminal trials.

It may be the case that, through the much-vaunted process of globalisation, the growing international interest in restorative and diversionary processes will eventually exert much greater influence on the development of both inquisitorial and adversarial systems. There has been increasing evidence of an emergence of something approaching an international consensus on best trial practice over the past decade in terms of the values, structures and procedures that underpin the criminal process. ${ }^{106}$ As international human rights and criminal justice discourse increasingly converge, the stark delineation of civil and criminal law, as well as 'public' and 'private' interests as discrete entities, is becoming less marked. Traditional power structures and the organisation of society are undergoing a sea-change, against the backdrop of increased emphases being placed upon individual rights, public service values and the concept of a pro-active, civil society. ${ }^{107}$ As suggested above, the very concept of victim participation would appear to be a direct corollary of a modern, liberal criminal justice system that purports to follow emergent trends in best practice.

In specific relation to victims' rights discourse, there appears to be a consensus that the effective resolution of criminal disputes requires that crime is not only viewed as an offence against society, but also as a dispute between the victim and the offender. ${ }^{108}$ Restitution and reconciliation are increasingly being mainstreamed as values that ought to be safeguarded by the criminal process. Punishment, it seems, is

\footnotetext{
106 See generally N. Jorg, S. Field and C.Brants, 'Are Inquisitorial and Adversarial Systems Converging?’ in C Harding, P Fennell, N Jörg \& B Swart (eds) Criminal Justice in Europe (1996); D. Amann, 'Harmonic Convergence? Constitutional Criminal Procedure in an International Context' (2000) 75 Indiana L.J. 809. For an overview of convergence in penal policy generally see T. Jones and T. Newburn, 'Policy Convergence and crime control in the USA and the UK: Streams of Influence and Levels of Impact' (2002) 2(2) Crim. Justice 173.

${ }^{107}$ Faulkner (2001), op cit n.3., p344. See more generally M. Ryan, Penal Policy and Political Culture in England and Wales (2003), esp. pp 75-107; N. Bardouille, 'The Transformation of Governance Paradigms and Modalities: Insights into the Marketization of the Public Service in Response to Gloablisation' (2001) 6 Georgetown. Pub. Pol'y Rev. 155.

${ }^{108}$ J.Doak, op. cit. n.39, p.31.
} 
being increasingly sidelined in favour of restorative-based models which emphasise reparation and participation, ${ }^{109}$ signalling a shift in criminal justice discourse away from the neat dichotomy which has traditionally separated public and private interests.

Of course, such challenges to the traditional punitive paradigm are riddled with priority-based conflicts, concerning, for example, whether compensation ought to take priority over any punitive sanction, or whether (and in what precise circumstances) the victim's interest can prevail over the collective interest. It was noted above, for instance, that the victim's interests in how the criminal trial is conducted may well conflict with those of the prosecution, in which case they will automatically be laid to one side for the public good. In advancing the idea of victim participation in the trial, the need for certainty dictates that such questions are thoroughly addressed, but it does not necessarily assert that entirely separate legal structures are necessary to effectively safeguard public and private interests. As Van Ness has argued, the key question relating to victim participation is not how to avoid conflicts between competing interests, but how to manage them effectively, so that as many of the competing interests as possible are accommodated in a principled manner. ${ }^{110}$

One of the major challenges for criminal justice in the next decade will be the task of redefining the developing relationships between the victim, the accused and the State in such a way that takes on board current trends in human rights and criminal justice discourse towards a more inclusive model of criminal justice. While the determination of guilt should always be the focus of criminal trials since the risks of injustice are not the same for the victim and the defendant, the accused must always be at the centre of proceedings. ${ }^{111}$ However, this does not mean the criminal justice system should not take account of other interests or other objectives. Spencer argues that a key subsidiary aim of proceedings should be to inflict 'as little pain as possible... to everyone concerned. ${ }^{112}$ While the interests of certainty and public policy require that

\footnotetext{
${ }^{109}$ See S. Walther, 'Reparation and Criminal Justice: Can they be integrated?' (1996) 30(3/4) Israel L. R. 316, 320-322.

${ }^{110}$ D. Van Ness, ‘A Reply to Andrew Ashworth’ (1993) 4(2) Crim. L.F. 301, 304.

111 J. Jackson, 'Putting Victims at the Heart of Criminal Justice? The Gap Between Rhetoric and Reality' in E. Cape (ed), Reconcilable Rights? Analysing the Tension between Victims and Defendants (2004), 70.

112 J. Spencer, 'Criminal Procedure: The Rights of the Victim versus the Rights of the Defendant' in E Cape (ed), Reconcilable Rights? Analysing the Tension between Victims and Defendants ( (2004), 37.
} 
decision-making is always exercised by a non-partisan adjudicator, it does not necessarily follow that any input of the victim should be incapable of being considered as one of many factors in this process. Giving victims of crime the opportunity to tell their story in their own words a secure and relaxed atmosphere is not only necessary to protect the interests of individual victims, but it also has the potential to act as an indispensable aid to truth-finding. In doing so, this should serve not only the interests of victims, but also the integrity of the criminal justice system as a whole. 